\title{
Stone Money of Yap as an Early form of Money in the Economic Sense
}

http://doi.org/10.21272/fmir.5(2).114-119.2021

Paul F. Gentle, ORCID: https://orcid.org/0000-0002-0317-0166

Research Economist, Auburn University, Alabama, USA

\begin{abstract}
This article examines the special case of stone money, in Yap as a store of value, medium of exchange and unit of account, which are the three traits required for something to be considered money, in the economic sense. When confidence in a system of currency with coins is present, this more conventional form of money takes precedence. A respected economic form of currency with coins has all three elements of money: medium of exchange, store of value and unit of account. Though clearly, in a certain time period, stone money was the principle type of money. To a lesser extent, beads and shell were used as money. So, for a period of time, stone money, along with some use of beads and shells, constituted the medium of exchange. The focus of this article is on the stone money of Yap. Stone was obtained by quarrying on the island of Palau, some 500 to 600 years ago. A very interesting type of money in the past, was the stone money of Yap, more formally known as Rai, or Fei. These were doughnut-shaped, carved disks of normally calcite and, up to 4 meters (12 feet) in diameter. However, there are more smaller ones, with the smallest being as little as 3.5 centimeters (1.4 inches) in diameter. The people of Yap attributed value to the Rai. After the use of Rai faded away, German Marks and then later Japanese Yen and finally the U.S. Dollar, were the monetary standard. The prior use of Rai is the main interest of this article. Today Yap is an independent country, in a "free association" with the United States. A curriculum that somewhat resembles an American one is taught in schools on Yap. Tourism to Yap is an important activity. Currently, the U.S. dollar serves as the basis for money in the nation of Yap. It has been found that this stone money met the three criteria necessary for them to be an early type of money.
\end{abstract}

Keywords: defining money, Micronesia, Yap island, Caroline Islands, stone money.

JEL Classification: N00, N10.

Cite as: Gentle, P. F. (2021). Stone Money of Yap as an Early form of Money in the Economic Sense. Financial Markets, Institutions and Risks, 5(2), 114-119. http://doi.org/10.21272/fmir.5(2).114-119.2021

Received: 28 April,2021

Accepted: 2 June, 2021

Published: 25 June, 2021

Copyright: (C) 2021 by the author. Licensee Sumy State University, Ukraine. This article is an open access article distributed under the terms and conditions of the Creative Commons Attribution (CC BY) license (https://creativecommons.org/licenses/by/4.0/)

\section{Introduction}

A. Defining Money and Examples

In this article, an answer is sought to determine if stone money served well as a form of money on Yap Island, part of the Carolina Islands group. Currently, Yap refers to the main island in a group of four islands, with Yap being the largest. The three other primary islands associated with the main island of Yap are: Gagil, Map, Rumung. Most of the population of Yap lives on the island Yap, with smaller amounts of population on the other three islands, just specified. There are also much smaller islands and atolls. A somewhat American curriculum is used for education on Yap. Fitzpatrick (2004) states that 500 to 600 years ago, Yap islanders began the quarry process of obtaining the proper type of sone that was then used as money in Yap. In an earlier article, Fitzpatrick (2001) maintains that these stone money disks became part of a "complex political economy on Yap." Currently, Yap is an independent nation that is affected by the Compact of Free Association (2019) which also affects the United States and pertains to the relationship between the two nations. The next section will be a Literature Review, followed by an Analysis section and then a Discussion Section. Finally, a summary and conclusion section round out this article. 


\section{Literature Review}

Interestingly, money can be referred to "as anything that is generally accepted in payment for goods or services or in the repayment of debts" (Mishkin, 2006). Goldberg (2005) states that the stone money has intrinsic value to the people of the Yap island culture. As Mishkin (2006) points out, at times, money is paper and coins and this is what lay people first think of when they hear the word money. Furthermore, many economists may add in deposit accounts and financial instruments, such as bonds (Mishkin, 2006). Pearce (1986) states that sometimes, there has been the use of commodity money. With a commodity money system, the value of the commodity has value, determined by a society. A very interesting type of money in the past, was the stone money of Yap, more formally known as Rai, or Fei. These were doughnut-shaped, carved disks of normally calcite and, up to 4 meters (12 feet) in diameter. However, there are more smaller ones, with the smallest being as little as 3.5 centimeters (1.4 inches) in diameter. The people of Yap attributed value to the Rai. (Gilliland, 1975).

According to Mishkin (2006), in order for something to be money, three requirements must be met. These three requirements are being a store of value, having a unit of account and being a medium of exchange. There are special situations when something less familiar takes on traits of money, most often in an environment and time when currency with coins and other types of exchange are not present. For example, cigarettes were used as a type of money in prisoner of war camps in Germany during World War II (Radford, 1945). Prior to that, Native American wampum served as a means of recording treaties, histories, and sometimes messages within tribes and between tribes and other non-monetary uses, in what is now the Eastern part of North America. Yet, once European settlers came to America, the wampum started also being used as valued money, becoming a medium of exchange, in that area. Black beads of wampum were more valuable than white beads and so we can see an example of money having a unit of account. In part of Eastern North America, once Western European settlers came to the area until sometime in the eighteenth century, wampum was accepted as a medium of exchange, had units of account (black beads and white beads) and some store of value (Gentle, 2016). Similarly, various quantities of warehouse receipts served as money during part of the colonial period in Virginia. Receipts for tobacco during part of the time era of colonial Virginia, did satisfy all three requirements for something being money (Gentle, 2016, 2018). The store of value requirement would be at least somewhat satisfied (Radford, 1945). A cigarette can stay fresh for probably a shorter time than would tobacco aged in a warehouse or very large barrel.

An accepted currency with coin system would satisfy the three traits requirement well. Precious metals such as coins of gold and silver or notes, representing those precious metals, can also satisfy the necessary traits for something being money. The absence of such money causes some alternatives to be used and that was the case for the Yapese economy at one time.

\section{Analysis}

The research in this article shows how well did the use of stone money on Yap work. When other forms of money are not available or do not inspire enough confidence, then people may have confidence in certain commodities to serve as a type of money (Rothbard, 2002). For instance, during part of the history of colonial Virginia, warehouse receipts for tobacco were used between people as a form of money, since receipts were backed up by 100 percent tobacco (Brock, 1975; Rothbard, 2002). A comparable example would be rice in colonial South Carolina and some other parts of the World, at different times (Rothbard, 2002; Gentle, 2021). An examination of many different types of commodity money may be intriguing. Yet the focus of this article is on the use of stone money as a form of money, on the Island of Yap. Commodities such as tobacco fulfill a dual need. The tobacco is useful in tobacco products and as the basis for warehouse receipts, used as money in the Virginia colony for a time (Gentle, 2018). Beaver fur pelts also served as a source for useful product and as a type of commodity money in earlier times in certain places of North America (Gentle, 2020). Stone money is not what one would normally think of as a commodity, unless one was a person in they bygone days of Yap (Gilliland, 1975).

\section{A. Early history of producing stone money for Island of Yap}

By $500 \mathrm{AD}$, people from Yap were mining stones to be used as money from Palau primarily and only small amount were quarried on Guam for a short period of time. Palau has a main island amongst a group of other islands. The distance between Yap and Palau, is approximately 250 miles or 402 kilometers, something to keep in mind, when contemplating the long trip of the Yap people by canoe or raft, when stone money was moved from Palau to Yap. Later, foreign built ships were used to transport the stones. (Gilliland, 1975). 


\section{B. $\quad$ Subjective Value and more on Rai}

The subjective value would be determined by the degree of an individual's pleasure or displeasure in looking at and owning an item (Menger, 1871; Stigler, 1950; Mankiw, 2015). Amongst the native people of Yap, a type of stone money was called Rai. Clearly according to Goldberg, the Rai have "intrinsic value" for the people of Yap. Also, today the form of money used is the U.S. dollar, since Yap has been affiliated with the United States, of varying degrees since the end of World War II. Now Yap is a sovereign nation, with a free association to the United States. Yap is also a tourist destination. (Gillilland, 1975). Native people of Yap have high regard for Rai. It is forbidden to stand on top of the stone money and forbidden to sit on it (Office of the District Administrator, 1966; Gillilland, 1975). The author of this article thinks it is interesting how in Thailand, even currently, some people often do not flip coins to figure out one of two answers, when a portrait of the Thai king is on one side of the coin, for fear that that side of the coin would end up face down on the ground, after the toss. So, this Thai story has to do with money and the reverence for the Thai monarchy, a subjective value.

Neither gold nor silver, were native to Yap, and one alternative to precious metals backed money was to create $R a i$, from material from Palau. The Rai, somewhat resemble a millstone but the Rai were not meant to be used to mill wheat or to process any other inputs for the production of food. Yet at one time, it was primarily Rai or stone money that was the medium of exchange on Yap. There is a story of a piece of Rai being mined, prepared and while it was in transport, it fell into the sea. Nonetheless it held its value and the attitude was this. Although it is on the bottom of the ocean floor, that piece of Rai could still be used to purchase goods and services (Gilliland, 1975).

Overtime, there has been more contact between Yap natives and more technologically advanced nations and some interesting results have occurred. Ships became available to transport the Rai. Trade involving curcuma and copra, in exchange for iron and other items, occurred between the natives of Yap, Palau and other islands, at different times. Yap was occupied by the Japanese, including during the period when many Japanese aggressive military occupations took place in some areas surrounding the Pacific Ocean and on many islands in the Pacific Ocean. At that time, many of the then existing Rai were stolen and used for military purposes, such as the construction of walls and used as sea anchors. Compared to other occupiers of Yap, through the years, the World War II Japanese were especially harsh on the native people of Yap (Gillilland,.1975). Furthermore, some natural history museums in different countries have examples of Rai, including large ones, proudly on display (Gillilland, 1975).

How well did Rai fulfill the criteria necessary for Rai to be considered money in the modern economic sense? Clearly stone money was the main type of money, before the advent of the use of U.S. dollars. To a lesser extent, beads and shells were also used as money. So, for a period of time, stone money, along with some use of beads and shells, constituted the medium of exchange. Also, the fact that there was widespread use of Rai and the beads and shells, in Yap at one time is evidence of the medium of exchange requirement for being money. After the use of Rai faded away, German Marks and then later Japanese Yen and finally the U.S. Dollar, were the monetary standard. The prior use of Rai is the main interest of this article. Regarding the store of value requirement of money, the actual values of individual Rai were due to the size of the Rai (Gilliland, 1975). Gilliland (1975) clearly notes that as late as the nineteenth century and somewhat beyond. "one needed money for the purchase of food in this substance for the purchase of food in this subsistence economy." Also, an example provided by Gilliland (1975) notes "that a small rai, the size of a plate and thick as an upper arm, would buy a family's monthly supply of fish, yams, and taro." Therefore, the unit of account requirement for $R a i$ to be considered money is fulfilled. Through the size of Rai did indeed determine its value, there was another factor for certain situations. Yet the value could change some, partially based on if the previous owner of a particular Rai, was of high social status . ${ }^{1}$ Even though the item is or was used as a medium of exchange, the value of Rai has to do primarily with both the size of the rai and in some cases with the prior owner of a particular Rai (Gillilland,1975). Rai were sometimes used in ceremonial purposes or as collateral, as part of an exchange of some sort. The value and ownership of Rai were recorded orally. It was not even necessary for the Rai to be physically moved from owner to another, just as long as the Yap people knew the respective current owners of different Rai (Gillilland, 1975; Doveski, 2017). The Rai were recognized by all as a viable medium of exchange. Furthermore, there were different sizes of Rai, perhaps enough for the unit of account requirement for being money (Federal Reserve Bank of Atlanta, 2019).

\section{Quantity Theory of Money Considerations}


In Gentle (2018) it was shown that warehouse receipts for tobacco in colonial Virginia can be an example of money, fitting the Quantity Theory of Money. The Quantity Theory of Money's four factors can be as shown this way: $\mathrm{M}$ denotes the money supply; $\mathrm{V}$ denotes the Velocity of money; P denotes the price level and Q stands for Quantity of goods and services. M could be stone money or tobacco receipts. More of M would result in price increases for $\mathrm{Q}$, if $\mathrm{M}, \mathrm{V}$ and $\mathrm{Q}$ were constant. If $\mathrm{M}$ was increasing in any of the trips, that retrieve more Rai. (The tribal chiefs of the Yap people decide when there is a need for more Rai.) It would be difficult to get actual values of the $M$ and $P$, due to the aforementioned complex considerations in measuring the value of Rai, as described by Gilliland (1975).

\section{Discussion}

\section{A. An important difference between Yap money and Native American Wampum.}

Yap stone money is different than Native American money, in how the two types of money came about. The explanation below concurs with what is stated in this article. Gentle (2016) states:

This Yap example may prove to be more easily understood, since these stones were specifically created to be used as money by the native people of Yap before any contact with outside civilizations took place. That is a big difference between Yap stone money and Native American wampum. This is in contrast the Native American's wampum, which was mostly used for money, once the Native Americans had contact with European settlers. The function of Native American wampum for highly developed artistic, ceremonial, gift exchange, treaty making and the recording of Native American history were there prior to and after the advent of the European settlers. The use of wampum as a means of money came about after the Native Americans had contact with the European settlers (Gentle, 2016).

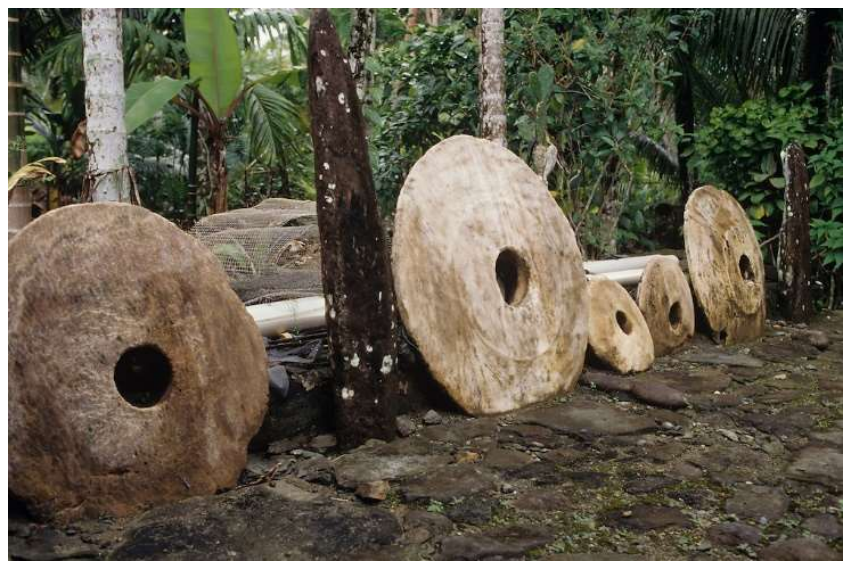

Figure 1. Above is a good illustration of Yap money

Source: johndemello.phtoshelter.com

B. Further thoughts on money holding value.

As Mishkin (2006) has stated, one of the required traits for something to be considered money, is being a store of value. This paper has mentioned several items that served as money. One common trait for these type monies is being a store of value. Yet some types of money will hold their value longer than other types. Interestingly, a cigarette may decompose in as little time as a few months. A cigarette meets the store of value requirement for money. Yet it may not last as long as tobacco in a warehouse or in a large barrel. So stored tobacco is a whole different product compared to cigarettes. Furthermore, stored tobacco holds its value longer than cigarettes do (Nettles, 1964; Gentle, 2018). Nevertheless, Wampum was made of shell beads and was thus more durable, than cigarettes or stored tobacco. Tobacco warehouse receipts held their value, served as a medium of exchange and met the unit of account trait necessary to be money (Gentle, 2018).

Therefore, one would probably wonder about gold and silver. How well do they retain value? Compared to the other items considered in Gentle, 2016, 2018; Gentle et al, 2017 and the Stone money of Yap, gold and silver have held their value quite well (Abdullah, 2013; Hart, 2013). Although very select paintings hold their value, as a general rule, art work is not a comparatively good investment, in monetary terms. It may have some intangible values, such as the utility, "psychic income" in owning a work of art (Ekelund et al, 2017). ${ }^{2}$ Over time, the type of money that may best hold its value, in many situations could be based upon gold and silver (Greenspan, 1966; Abdullah, 2013). Indeed, both gold and silver have been used for a time, as an important 
basis for money (World Gold Council, 2018). A detailed explanation of this goes beyond the scope of this article.

\section{Summary and Conclusion}

When conventional forms of money are not ubiquitous at all, people may turn to substitutes, such as wampum or tobacco in the form of cigarettes or with a receipt in a warehouse or rice. In this article, there has been a focus on the use of Rai during most of the history of Yap. These Rai fulfilled the three requirements for something to be money. The Rai were certainly valued by the people of Yap and used a medium of exchange. Thus, those two requirements were met. The units of account are given by the different size Rai, which had different values. Secondary to that is the possible additional worth which a Rai has based on that a prior owner of that particular Rai. After there was increased contact with the outside world, the people of Yap used in succession, German money, Japanese money and now a monetary standard of the United States of America, became more and more important to Yap. Yap Stone money was an economic form of early money part of Yap history. As the economic history of a place progresses, one can expect the forms of money to sometimes change. So, it was with Yap. ${ }^{2}$

Endnote (1) Examining the Rai described in the article, is done sometimes by economist and sometimes anthropologists. Herskovits (1965), views economists as primarily concerned with material welfare, while anthropologists care about relationships. The fact is economists care about material welfare and relationships. The service sector and goods sector of an economy are very much about relationships that concern goods and services. Also, economists sometimes use a non-pecuniary approach. Economics is a social science and as with some other social sciences, takes into consideration an unlimited number of factors in explaining human behavior, including how this relates to institutions, such as government, firms, and others. Both economics and anthropology can simultaneously add to many discussions of social science topics. (Gentle, 2016; Gentle and Giliberti, 2017; Gentle, 2018).

Endnote (2) In Gentle and Giliberti (2017), the reality of art works during the Nazi era being used to hold value was examined. Though the art certainly had a store of value, it could not be broken down into units of account; nor was it the medium of exchange for the general society. Therefore, art during the Nazi era failed to meet all three criteria necessary for something to be considered money in the economic sense.

\section{References}

1. Abdullah, Adam (2013). Examining the Value of Money in America over the Long Term (1792-2009), International Journal of Economics and Finance, 5(10), 58-84. [Link]

2. Brock, L. V. (1975). The Currency of the American Colonies: 1700 -1764: A Study in Colonial Finance and Imperial Relations, New York: Arno Press.

3. Compact of Free Association (2019). About the Compact of Free Association. [Link]

4. Docesvksi, Boban (2017). The Rai Stones are huge stone wheels used as currency on the island of Yap, The Vintage News. [Link]

5. Ekelund, R. B., Jackson, J. D., Tollison, R. D., (2017). The Economics of American Art: Issues, Artists and Market Institutions, Oxford University Press. [Link]

6. Federal Reserve Bank of Atlanta (2019). Classroom Economist. What is Money? An Economist's Perspective (Transcript), Atlanta Federal Reserve Bank. [Link]

7. Fitzpatrick, S. M. (2001). Archaeological investigation of Omits Cave: A Yapese Stone Money Quarry in Palau, Archaeology in Oceania, October, 36, 3, 153-162. [CrossRef]

8. Fitzpatrick, S., (2004). Banking on Stone money, Archaeology, 57(2), 18 - 23. [Link]

9. Gentle, P. F. (2016). Native American Wampum for Non-Monetary Uses and For Use as Money, Public and Municipal Finance, 3, pages 16 - 21. [CrossRef]

10. Gentle, P. F., Giliberti, M. (2017). Were Valuable Art Works an Economic form of Money during the Third Reich period in Germany? Public and Municipal Finance, December, 33-38. [CrossRef] 
11. Gentle, P. F., (2018). Were Warehouse Receipts for Tobacco an economic form of money during the Colonial period in Virginia, Public and Municipal Finance, 7(1), 37-42. [CrossRef]

12. Gentle, P. F. (2020). Beaver pelts as an Early form of Money in the Economic Sense: Satisfying Store of Value, Unit of Account and Medium of Exchange Requirements, Strategies in Accounting and Management, 2(2), December, 1-3. [Link]

13. Gentle, P. F. (2021). Rice as an Early form of Money in the Economic Sense: Satisfying Store of Value, Unit of Account and Medium of Exchange Requirements, SocioEconomic Challenges, 5(1), 51-56. [CrossRef]

14. Gilliland, Cora Lee, (1975). The Stone Money of Yap, Washington, D.C.: Smithsonian Institute. [CrossRef]

15. Goldberg, D. (2005). Famous Myths of Fiat Money, Journal of Money, Credit and Banking, 37, 5, October, 957-967. [Link]

16. Greenspan, A. (1966). Gold and economic freedom. The Objectivist Newsletter. [Link]

17. Hart, M. (2013). The Race for the World's Most Seductive Metal, Simon and Schuster. [Google Scholar]

18. Hersokovits, M. J. (1965). Economic Anthropology: The Economic Life of Primitive Peoples. New York: W.W. Norton, Incorporated. [Link]

19. Mankiw, N. G. (2015). Principles of Economics, Stamford, CT: Cenage Publishers. [Google Scholar]

20. Menger, Carl, (1871). Principles of Economics. Original title: Grundsätze der Volkswirtschaftslehre Auburn, AL: Ludwig Von Mises Institute. [Link]

21. Mishkin, Frederic S. (2006). The Economics of Money, Banking, and Financial Markets, New York: Pearson Addison-Wesley.

22. Nettles, Augustus M. (1964). The Money Supply of the American Colonies before 1720, New York: Sentry Press. (Reprint of 1934 edition.). [Link]

23. Office of the District Administrator (1966). Welcome to Yap, Office of the District Administrator, Yap, Western Caroline Islands, October. [Link]

24. Pearce, David W. (1986). MacMillan Dictionary of Modern Economics, New York: Macmillan Publishing Company. [Link]

25. Radford, R.A. (1945). The Economic Organization of a P.O.W. Camp, Economica, 12, 48, 189-201. [Link]

26. Rothbard, M. N. (2002). A History of Money and Banking in the United States: The Colonial Era to World War II, Auburn, Alabama: Ludwig Von Mises Institute. [Link]

27. Stigler, G. (1950). The Development of Utility Theory, The Journal of Political Economy, August, 58, 4, 307-327. [Link]

28. World Gold Council. (2018, July 9). Money and Gold. Gold's role as money. History of gold. [Link] 